\title{
IAMJ
}

INTERNATIONAL AYURVEDIC MEDICAL JOURNAL

\section{CONCEPTUAL STUDY OF DENGUE FEVER ON THE BASIS OF AYURVED}

\author{
Dattatray. L. Shinde ${ }^{1}$, Yogita L. Mohite ${ }^{2}$
}

${ }^{1} \mathrm{Md}$. PhD., Professor, HOD, ${ }^{2}$ Post Graduate Scholar, Department of Kayachikitsa, BVDU, College of Ayurved, Pune- 411043, Maharashtra, India

Corresponding Author: yogmohite31@gmail.com

\section{https://doi.org/10.46607/iamj2209042021}

(Published Online: April 2021)

Open Access

(C) International Ayurvedic Medical Journal, India 2021

Article Received: 25/03/2021 - Peer Reviewed: 27/03/2021 - Accepted for Publication: 31/03/2021

Check for updates

\begin{abstract}
Dengue fever is one of arthropod born and epidemiological disease caused by Arbovirus carried by vector Aedes aegypti. Dengue is the most rapidly spreading mosquito borne viral disease in the world. The survey findings indicated that $49 \%$ of country's population had been previously infected with DENV. Due to rapid urbanization, lifestyle changes and deficient water management including improper water storage practices in urban, peri urban and rural areas, leading to proliferation of mosquito breeding sites. Dengue fever has a seasonal pattern, the cases peak after monsoon not uniformly distributed throughout the year. Incubation period of 2-7 days. Fever, malaise, retro-orbital pain, headache, arthralgia, petechiae, itching are common features. Thrombocytopenia is common. Macular rash may occur on first day. Illness may last a week with additional symptoms such as nausea, vomiting, anorexia, marked cutaneous hypersensitivity. Maculopapular rash begins on the trunk spreading to extremities and face. Leucocytes and platelets numbers decreases. Serum aminotransferase level may rise. IgM ELISA or paired serology test should be done at the phase of recovery. Antigen detection ELISA or RT-PCR during acute phase should be done. Due to Jwara Nidan, Pachakagni produces Doshakar Dravya which imbalances Tridosha. Ushma is necessary for Jwalan (burning) of this Doshkar Dravyas. Doshkar Dravya causes Kshobh to Vata Dosha and particularly Saman Vayu, causes more Agni Prajwalan and increases Ushma. Excessive increase in Ushma leads to Ojasthana Hriday Dushti, Tarpak Kapha in Shira Dushti, Shirashta Indriyadushti, Pranasthana Dushti.
\end{abstract}

According to Samhita study, dengue fever can be correlated to Agantu Jwara, Sannipatik Jwara, Dandak Jwara and Vishamjwara. 
Keywords: Doshakar Dravya, Jwara Nidan, Pachakagni, Tridosha, Ushma

\section{INTRODUCTION}

Dengue fever is one of the epidemiological and arthropod borne disease caused due to virus carried by vector Aedes aegypti. Zoonotic viruses are transmitted in nature without regards to humans. Few agents are regularly spread among humans by arthropods. Most of the viruses either maintained by arthropod or chronically infected rodents. Zoonotic viruses from at least seven families act as significant human pathogens as follows ${ }^{1}$

1. The Arenaviridiae

2. The Bunyaviridae.

3. Flaviviridae.

4. Filoviridae.

5. Reoviridae.

6. Rhabdoviridae.

7. Togaviridae.

\section{Flavivirus leads to}

Hemorrhagic fever: yellow fever, hemorrhagic fever, fever, myalgia such as dengue virus,

Encephalitis due to St Lowis, Japanese, West Nile, Murray Valley encephalitis, Rocio virus.

Dengue viruses are arboviruses capable of infecting people. These infections may be asymptomatic or may lead to (a) "classical dengue fever", or (b) dengue hemorrhagic fever without shock or (c) dengue hemorrhagic fever with shock.

The dengue flavivirus is spread by the vector mosquito Aedes aegypti and is endemic in South-east Asia, India, Africa and the Americas. The incubation period following the mosquito bite is $2-7$ days, with a prodrome of malaise and headache, followed by morbilliform rash, arthralgia, pain on eye movement, headache, nausea, vomiting, lymphadenopathy and fever. The rash spread centrifugally, spares the palm and the soles and may desquamate on resolution. The disease is self-limiting, but convalescence is slow. ${ }^{2}$

Due to rapid urbanization, lifestyle changes and deficient water management including improper water storage practices in urban, peri urban and rural areas, leading to proliferation of mosquito breeding sites. Dengue fever has a seasonal pattern, the cases peak after monsoon not uniformly distributed throughout the year. During 2013, about 73,168 cases were reported with 168 deaths. The case fatality rate was $0.22 \%$. All the four serotypes i.e. dengue 1,2,3 and 4 have been isolated in India but at present DENV-1 and DENV-2 serotypes are widespread. ${ }^{3}$

In Ayurved Granthas (textbooks) most of the Acharya have given $1^{\text {st }}$ preference to Jwara Nidan (cause) \& its Chikitsa (treatment). Many Acharya have termed Jwararoga as ROGADHIPATI (king of diseases) because of its uniqueness to make everyone suffer anytime from birth to death. Jwara is included in Ashtamahagada (eight major diseases) by Acharya Charak. Charakacharya have mentioned following types of jwara i.e. Vataja, Pittaja, Kaphaja, VataPittaja, Vata-Kaphaja, Kapha-Pittaja, Vata-PittaKaphaja and Aagntujwara.13 varieties of Sannipataj Jwara has been described based on the predominance of Doshas. Four types of Agantu Jwara have been explained. Vishamjwara which one is based upon pattern of Jwaravega due to Doshagati. It is of five types: Santata, Satata, Anyedushka, Tritiyak and Chaturthak. Dhatugata Jwara Awastha also have been explained.

Jwara pradhanya is due to

1) Deha-Indriya Manastapi- Jwara manifests due to affliction of both Sharira (physical) and Manasa (mental) doshas

2) Sarva-Rogagraj.(leading disease)

3) Balavan.(powerful)

4) Which one is present at the time of birth and death.

Fever manifest from the anger of Lord Shambhu, loss of complexion, loss of digestive fire, king of disease and group of many diseases. because of its widespread affecting all living beings, difficult to cure with the chance of causing death and it is the killer of all living beings. Cardinal signs and symptoms of Jwara are increased body temperature associated with mental unpleasantness. It afflicts the body, mind and other sense organs. No living being is spared by affliction of 
Jwara. That's why Jwara Vyadhi is considered as most important disease and king of all diseases.

Dengue fever caused by virus is one of the leading diseases across the worldwide. It is necessary to study dengue fever on ayurvedic concepts and research with ayurvedic drugs on dengue fever.

\section{Transmission}

\subsection{The Virus:}

The dengue virus forms a distinct complex within the genus flavivirus based on antigenic and biological characteristics. Dengue virus (DEN) is a single stranded RNA virus comprising four distinct serotypes (DEN-1 to -4). Although all four serotypes are antigenically similar, they are different enough to elicit cross protection for only a few months after infection by any one of them. Secondary infection with dengue serotype 2 or multiple infection with different serotypes lead to severe form dengue DHF/DSS. ${ }^{4}$

\subsection{The Vectors:}

Aedes aegypti and aedes albopictus are the two most important vectors of dengue. They both carry high vectorial competency for dengue virus, high susceptibility to infecting virus.

\subsection{Transmission of Disease:}

Arthropod borne viruses infect their vectors after the ingestion of a blood meal from a viremic vertebrate. The vectors become chronic, systemic infection as the viruses penetrate the gut and spread throughout the body. The viruses eventually reach the salivary glands during a period- extrinsic incubation that typically lasts 1-3 weeks in mosquito. At this point, arthropod is competent to continue chain of transmission by infecting another vertebrate when subsequent blood meal is taken. The arthropod is generally unharmed by infection, natural vertebrate partner has only transient viremia.

Alternative mechanism for virus maintenance in its arthropod host is transovarial transmission, common along family Bunyaviridae. ${ }^{5}$

\subsection{Environmental Factors}

The population of Aedes agypti fluctuates with rainfall and water storage. Its life span is influenced by temperature and humidity, survives best between $16 \mathrm{c}$ to $30 \mathrm{c}$ and a relative humidity of $60-80 \%$. It breeds in the containers in and around the houses. Even $2 \mathrm{c}$ increase in the temperature the extrinsic incubation period of DENV will be shortened and more infected mosquitoes will be available for longer duration. Along with that mosquito will bite more frequently because of dehydration and increase man mosquito contact. $^{6}$

\section{Increased Destruction of Platelets Causes Thrombocytopenia In Dengue ${ }^{7}$}

Thrombocytopenia may also be due to (1) platelet consumption during ongoing coagulopathy process, (2) activation of the complement system, or (3) increased peripheral sequestration. It has been shown in vitro that platelets undergo increased phagocytosis by macrophages in patients with secondary DENV infection by an uncharacterized mechanism. It has also been demonstrated that DENV patients develop anti-platelet antibodies of the IgM isotype. Anti platelet antibodies cause platelet lysis, as measured by using lactate dehydrogenase activity

Some studies have shown platelet activation and apoptosis in dengue infected patients. In this way, platelet apoptosis, platelet phagocytosis, serum TPO levels significantly increased in patients during the acute and early convalescence phases compared to levels in patients during the convalescence phases and in healthy volunteers.

\section{Platelets Dysfunction in Dengue}

A number of studies have documented platelet dysfunction in DENV infection. In this context, the suppression of platelet aggregation was demonstrated during the acute phase of DHF in both shock and nonshock patients, with a simultaneous increase in release of beta thromboglobulin (BTG) and platelet factors 4 (PF4) from platelets into plasma. Production of platelet activating factor (PAF), Thromboxane B2, and prostaglandin D2 was measured in mononuclear leukocytes from nonimmune and previously DENV-1 infected donors when infected in vitro with DENV 2.

\section{Signs \& Symptoms}

Prodrome of malaise and headache, followed by a morbilliform rash, arthralgia, pain on eye movement, headache, nausea, vomiting, lymphadenopathy. and 
fever. The rash spreads centrifugally, spares the palm and the soles, and may desquamate on resolution. The disease is self-limiting but convalescent is slow.

\section{Natural History of Dengue Fever ${ }^{8}$}

1) Febrile Phase-Following an incubation of 4-6 days, the illness commonly begins with high grade fever accompanied by facial flushing, headache. Anorexia, vomiting, epigastric discomfort is common. On Occasion temperature may be $40-41{ }^{\circ} \mathrm{C}$ and febrile convulsion may occur particularly in infant.

2) Critical phase- When the temperature drops to 37.5-38 ${ }^{\circ} \mathrm{C}$ are less and remains below this level, usually on $3-7^{\text {th }}$ day of illness, an increase in capillary permeability may occur. This marks the beginning of the critical phase. The phase of clinically significant plasma leakage usually last 24-48 hrs. Progressive leukopenia followed by a rapid decrease in platelet count usually precede plasma leakage. The degrees of plasma leakage vary. Shock occurs when a critical volume of plasma is lost through leakage.

3) Convalescent phase/ recovery phase- Patient who survives the $24-48 \mathrm{hr}$ critical period will begin to reabsorb the fluids that leaked from intravascular space.

\section{Ayurved View-}

As it is external cause, it will be considered as Agantu Dosha (external cause) and Jwara (fever) type as Agantu jwara (fever due to Infection). Due to virus potency (Agantu Dosha) Vyadhi occurs first i.e. establishment of fever occur first and then Dosha Dushti (Vitiation of dosha) will occurs. Later phase of Dosha Dushti occurs due to Agnimandya (Decreased digestive capacity) and symptoms like Agniamandya, Aruchi (ageusia), Shirashoola (headache), Sandhishoola (arthralgia) establishes as Dosh-dushya Sammurchana (Complex of Dosha-Dushya) happens. Vitiated Dosha will go at place of Sthanavaigunya (site where pathogenesis occur) and because of Rasavaha Strotas Avarodh (obstruction of Rasavaha Strotas) Jwara occurs. Furthermore, dengue fever due to virus can be correlated as Abhishangaja Jwara (One of the type fevers caused due to external cause). ${ }^{9}$ Alasya (laziness), Arati (restlessness), Gatragaurav (heaviness), Aruchi, Asyavairasya (bad taste),
Angamarda (bodyache), Romharsha (shudder, chills) are common prodromal symptoms before fever occurs. According to modern study, there are 3 phases of dengue fever: Febrile phase, Critical phase and Recovery phase. Sudden high-grade fever in the febrile phase after being infected shows Pitta Dushti. Symptoms like bodyache, headache, myalgia, arthralgia shows vitiated Vata Dosha. Anorexia, nausea, vomiting shows digestive system improper function and can be correlated to Agnimandya and Kaphaprakopa. Symptoms like cough, cold are also common which also shows Kapha Dosha Dushti. Facial flushing, skin erythema indicates Rasa, Rakta Dhatu Dushti.

Further at critical phase, there is an increase in capillary permeability. Dharan (to hold) or Sthairya (stability) is Prakrut Karma (physiological function) of Kapha Dosha. Increase in capillary permeability can be related to Kapha Dushti again. Due to capillary leakage, fluid goes in the extracellular fluid and symptoms like ascites, pleural effusion occurs. This can be correlated to Shotha (inflammation) like condition, Rasavaha Strotas, Udakwaha strotas and Rasa Dhatu Dushti.

Leucopenia and thrombocytopenia are common picture seen in dengue fever. According to modern these are blood component. According to Ayurved, among all the diseases the root cause is Agnimandya (Decreased digestive capacity). Agni is of 13 types according to their function site: Jatharagni (Agni present at Amashay), Dhatwagni (Agni of Dhatu), Panchabhautik Agni (Agni of Panchamahabhuta). Agni is important for conversion of any form to another. Pitta-Rakta remain at Ashrayashrayi (interrelated)Bhava. Agni is nothing but one of the forms of Pitta. Agnimandya and Doshaprakopa causes Agnimandya and further Dhatu nourishment doesn't occur as of Rakta, and hence thrombocytopenia occurs due to virus impact.

Based on Ayurved literature most of the symptoms of dengue fever seen in Sannipatik jwara. ${ }^{10}$

After having glance upon the reference; symptoms like Asthi-Sandhi-Shiroruja (Arthralgia, myalgia, jointpain, headache), Kasa (cough), Shwasa 
(dyspnoea), Aruchi, Bhrama (giddiness), Raktapittastheevan (haemoptysis), Shyav-Rakta Varni Kotha (elevations), Mandal Utpatti (petechia) can be seen as dengue fever infection. This probable combination of Dosha and Dushya according to their Bala (potency) is called as Vikruti-Vishamsamavay. It is not necessary to have all the symptoms of classical dengue fever to be seen in the patient. According to case history taking and present Lakshana, Dosha-Dushya study should be done.

According to Dosha its Bala and Kala dominating factors, Jwara is further classified as Vishamjwara.
The dengue fever pattern is classically biphasic or "saddleback". Breaking and then returning for 1 or 2 more days. As there is Vishamata (imbalance) in Jwara pattern it will be also considered as Vishamjwara.

Among the Sansarga type (combination of two dosha), Vata-Kapha Jwara shows more correlation with dengue fever.

In the Parishishta Adhyay of Madhav Nidan, Acharya has mentioned one type of Jwara i.e. Dandak Jwara in which dengue correlation can be found. ${ }^{11}$

\section{Dengue Samprapti}

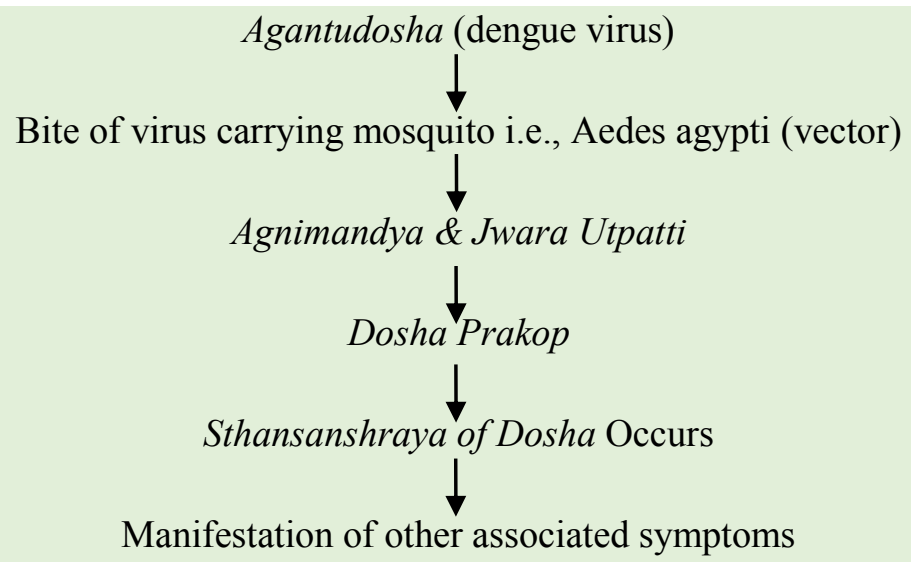

\section{Treatment ${ }^{12}$}

1) Langhan- taking light diet or complete fast should be advised.

2) Ushnodak (warm water)

3) Pachan drugs and Jwaraghna Kashay (antipyretic drugs)

4) Yavagu.

\section{DISCUSSION}

Due to Vikrut Ahar, Vihar, Agantu Dosha, Pachakagni produces Doshakar Dravya (stimulative factor for vitiation of Dosha) which imbalances Tridosha. Ushma is necessary for Jwalan (burning) of this Doshkar Dravyas. Doshkar Dravya causes Kshobh to Vata Dosha and particularly Saman Vayu, causes more Agni Prajwalan and increases Ushma. Increasing Ushma leads to increasing Pachan Karya of Dhatwagni to kill the Doshkar Dravya. Rise in Ushma is beneficial for health upto certain limit but excessive increase in Ushma leads to Ojasthanashriday Dushti, Tarpak Kapha in Shira Dushti, Shirashta Indriyadushti, Pranasthana Dushti. Deha and Mana Vikruti occurs in Jwara Vyadhi and hence Arati, Vaichitya Lakshana occurs.

\section{Benefits of Tikta Rasa dravya in jwara vyadhi}

The Madhur Rasa Pradhan Dravya are Rasapradhan (rasa dominant) while Tiktadi rasa Pradhan Dravya are Veeryapradhan (veerya dominant) i.e. they work in our body through Veerya. Tiktadi Rasa Pradhan Dravya are having Vayu + Akash Mahabhutas which are excellently useful to treat Santarpanothha Vyadhi (Vyadhi occurs due to Prhithvi and Aap Mahabhuta dominance). Tikta Rasa has been mentioned Jwaraghna in Ayurvedic text. Amashay Bala is also maintained by Tikta Rasa. Tikta Rasa is also having Laghu, Rasadhatugami property and hence it is extremely beneficial to treat Jwara Vyadhi. 


\section{CONCLUSION}

Dengue fever is one of the leading Arthropod borne and epidemiological disease worldwide. According to Samhita it can be studied as a Jwara Roga. It can be correlated as Agantu Jwara, Sannipatik Jwara, Dandak Jwara and Vishamjwara. Regimen stated in Jwara Adhyay should be followed. Langhan, Ushnodak, Jwaraghna Kashay, tablets, Yavagu should be followed. Since no vaccination is available, it is necessary to build immunity of the people. Proper Dincharya, Ritucharya (lifestyle regimen), AharVihar Paricharya should be followed to get Yuktikruta Bala (acquired immunity).

\section{REFERENCES}

1. Longo Dan, Kasper Dennis, Jameson J. Larry, Harrison's principles of internal medicine, Chapter 196, Mc Graw Hill, USA, 2012, $18^{\text {th }}$ edition, page 1617.

2. Dr. Park. K, Preventive and social medicine, Chapter 5, Bhanot publication, Jabalpur, Jan 2015, $23^{\text {rd }}$ edition, page 246.

3. Dr. Park. K, Preventive and social medicine, Chapter 5, Bhanot publication, Jabalpur, Jan 2015，23 ${ }^{\text {rd }}$ edition, page 246.

4. A joint publication of the World Health Organization and the Special Programme for Research and Trading in Tropical Diseases(TDR),Dengue; Guidelines for diagnosis, treatment, prevention and control, WHO \& TDR, WHO press,20 Avenue Appia, Geneva 27, Switzerland, 2009, page 14.

5. A joint publication of the World Health Organization and the Special Programme for Research and Trading in Tropical Diseases (TDR), Dengue; Guidelines for diagnosis, treatment, prevention and control, WHO \& TDR,WHO press,20 Avenue Appia, Geneva 27,Switzerland,2009, page 14.

6. Dr. Park. K, Preventive and social medicine, Chapter 5, Bhanot publication, Jabalpur, Jan 2015, $23^{\text {rd }}$ edition, page 247.

7. Elzinandes leal de Azeredo, Monterio Robson, Thrombocytopenia in dengue: interrelationship between Virus and imbalance between Coagulation and Fibrinolysis and Inflammatory mediators, Hindawi, Article ID 313842, 2015.

8. A joint publication of the World Health Organization and the Special Programme for Research and Trading in Tropical Diseases (TDR), Dengue; Guidelines for diagnosis, treatment, prevention and control, WHO \& TDR,WHO press, 20 Avenue Appia, Geneva 27,Switzerland, 2009, Page 26.

9. Dr. Brahmanand Tripathi, 2015, Charaksamhita Purvardh, Choukhamba Surbharati Prakashan, Varanasi, page 592.

10. Vaidya Ya. Go. Joshi, Charaksamhita Uttarardh, Chikitsasthan chapter 3, Vaidyamitra Prakashan, Sadashiv Peth Pune, $4^{\text {th }}$ edition, 2013, Page 86.

11. Vaidya. Yadunandanopadhyay, Mahamatishrimadhavkarvirachitam Madhavnidanam, Parishishta adhyay, Choukhamba Sanskrit Bhawan, Varanasi, 1995, page-431.

12. Vaidya Ya. Go. Joshi, Charaksamhita Uttarardh, Chikitsasthan chapter 3, Vaidyamitra Prakashan, Sadashiv Peth Pune, $4^{\text {th }}$ edition, 2013, page 142.

\section{Source of Support: Nil Conflict of Interest: None Declared}

How to cite this URL: Dattatray. L. Shinde \& Yogita L. Mohite: Conceptual Study Of Dengue Fever On The Basis Of Ayurved. International Ayurvedic Medical Journal \{online\} 2021 \{cited April, 2021\} Available from: http://www.iamj.in/posts/images/upload/823 828.pdf 